\title{
Metvan, bis(4,7-Dimethyl-1,10-phenanthroline) sulfatooxidovanadium(IV): DFT and Spectroscopic Study-Antitumor Action on Human Bone and Colorectal Cancer Cell Lines
}

\author{
Ignacio E. León ${ }^{1}$ - María C. Ruiz ${ }^{1}$ - Carlos A. Franca ${ }^{1} \cdot$ Beatriz S. Parajón-Costa ${ }^{1} \cdot$ Enrique J. Baran ${ }^{1}$ \\ Received: 4 September 2018 / Accepted: 28 November 2018 / Published online: 5 December 2018 \\ (C) Springer Science+Business Media, LLC, part of Springer Nature 2018
}

\begin{abstract}
The complex bis(4,7-dimethyl-1,10-phenantroline)sulfatooxidovanadium(IV), commonly known as Metvan, was prepared using a known synthetic procedure. Its optimized molecular structure was obtained by DFT calculations, as it was impossible to grow single crystals adequate for a crystallographic study. The complex was also characterized by a detailed analysis of its infrared spectrum, supported by the theoretical calculations, and also by some data derived from its Raman spectrum. In addition, cytotoxicity studies were performed using human osteosarcoma (MG-63) and human colorectal adenocarcinoma (HT-29) cell lines. The results show that Metvan impaired cell viability of both cancer cell lines in a low concentration range $(0.25-5.0 \mu \mathrm{M})$.
\end{abstract}

Keywords Oxidovanadium(IV) · Metvan · DFT calculations · FTIR spectrum · Human bone and colorectal cancer cell lines

\section{Introduction}

Several animal and in vitro studies have clearly demonstrated the potential of simple and complex vanadium compounds in reducing or preventing neoplasia, and thus tumors, including cancer and its metastasis in various target issues [1-3]. In this context, and as a first important example of this activity, 35 years ago, it was demonstrated that vanadocene $\left(\eta^{5}\right.$ $\left.\mathrm{C}_{5} \mathrm{H}_{5}\right)_{2} \mathrm{VCl}_{2}\left(\mathrm{C}_{5} \mathrm{H}_{5}=\right.$ cyclopentadienyl $)$ effectively degenerates and kills Ehrlich ascite tumor cells [3-5]. After this discovery, an important and continuous development of this particular field of inorganic pharmaceutical chemistry takes place and a great number of vanadium compounds were synthesized and evaluated for anticancer activity [3, 6-9].

Between these compounds, bis(4,7-dimethyl-1,10phenanthroline)sulfatooxidovanadium(IV), now known as Metvan, was identified as a very promising multitargeted anticancer vanadium complex with apoptosis-inducing activity in different types of cancer cells and showing also high activity against cis-platin-resistant cancer cell lines [10-12].

Enrique J. Baran

baran@quimica.unlp.edu.ar

1 Centro de Química Inorgánica (CEQUINOR/CONICET, CICPBA, UNLP), Facultad de Ciencias Exactas, Universidad Nacional de La Plata, Bvd. 120 No. 1465, 1900 La Plata, Argentina
Notwithstanding, and in spite of these promising and multitargeted anticancer actions, no clinical assays were so far performed with this interesting drug, possibly due to the lack of information regarding its speciation in aqueous solution and its thermodynamic/redox stability.

Recently, a very interesting and complete speciation study of Metvan in aqueous solution and human blood was performed, which gave new insights into these aspects [13]. The speciation of Metvan in the blood depends mainly on the vanadium serum concentration. When the vanadium concentration is larger than $50 \mu \mathrm{M}, \mathrm{VO}^{2+}$ remains bound to $\mathrm{Me}_{2}$ ophen whereas for a vanadium concentration lower than $10 \mu \mathrm{M}$, the $\mathrm{VO}^{2+}$ cation is taken up by the cells, whereas a partial conversion of oxidovanadium(IV) to oxidovanadium(V) species may happen. Additionally, the effect of the free $\mathrm{Me}_{2}$ ophen ligand could add to that of the $\mathrm{V}(\mathrm{IV}) / \mathrm{V}(\mathrm{V})$ species [13-15].

In order to advance in a wider and deeper characterization of Metvan, we have made numerous attempts to obtain single crystals of this complex, adequate for crystallographic studies. Unfortunately, as all our attempts in this direction were unsuccessful, we have now derived its structural and geometric characteristics from a theoretical DFT study. Besides, the characterization was complemented with the analysis of its FTIR spectrum.

On the other hand, and to extend the information on the biological activities of Metvan, its antitumor potential against human osteosarcoma (MG-63) and human colorectal adenocarcinoma (HT-29) cell lines in culture was assayed. For 
comparative purposes, similar assays were also performed, using cis-platin instead of Metvan.

\section{Materials and Methods}

\section{Materials}

The 4,7-dimethyl-1,10-phenanthroline was purchased from Alfa Aesar, whereas $\mathrm{VOSO}_{4} \cdot 5 \mathrm{H}_{2} \mathrm{O}$ and all the other reagents and solvents were from Merck. cis-Platin was provided by Sigma Chemical Co.

Tissue culture materials were purchased from Corning (Princeton, NJ, USA), Dulbecco's modified Eagle's medium (DMEM) and TrypLETM from Gibco (Gaithersburg, MD, USA), and fetal bovine serum (FBS) from Internegocios SA (Argentina). All other chemicals, used in the biological assays, were from Sigma Chemical Co. (St. Louis, MO). MG-63 and HT-29 cell lines were purchased from ATCC.

\section{Synthesis of the Complex}

The complex was obtained, as previously described [16], by slow addition of an aqueous solution containing $0.25 \mathrm{mmol}$ of $\mathrm{VOSO}_{4} \cdot 5 \mathrm{H}_{2} \mathrm{O}$ to an ethanolic solution containing $0.5 \mathrm{mmol}$ of 4,7-dimethyl-1,0-phenanthroline. The reaction mixture was stirred at room temperature for $48 \mathrm{~h}$. The brown solid product was obtained removing the solvent and was washed with chloroform and ether and finally dried under a vacuum. Its purity was confirmed by elemental chemical analysis (Calcd. for $\left[\mathrm{VO}\left(\mathrm{SO}_{4}\right)\left(\mathrm{Me}_{2} \text {-ophen }\right)_{2}\right] \cdot 3 \mathrm{H}_{2} \mathrm{O} ; \mathrm{C}, 53.08 ; \mathrm{H}, 4.77 ; \mathrm{N}, 8.84$; S, 5.06; found C, 53.00; H, 4.83; N, 8.82; S, 5.02\%).

\section{Spectroscopic Characterization}

Infrared spectra in the spectral range between 4000 and $400 \mathrm{~cm}^{-1}$ were obtained with a Bruker EQUINOX 55 Fourier transform infrared spectroscopy (FTIR) instrument, using the $\mathrm{KBr}$ pellet technique. Raman spectra were obtained in the same spectral range with a Thermo Scientific DXR Raman microscope, using the 532-nm line of a Thermo Scientific solid-state laser diode pump for excitation. Unfortunately, these spectra show very poor quality, due to very unfavorable signal-to-noise ratios. Therefore, the obtained data are of limited value and only some of them were included in the discussion of the vibrational behavior of the complex.

\section{Cell Culture and Incubations}

MG-63 human osteosarcoma cells (CRL1427'TM) and HT-29 (HTB-38 ${ }^{\mathrm{TM}}$ ) human adenocarcinoma cells were grown in DMEM containing $10 \% \mathrm{FBS}, 100 \mathrm{U} / \mathrm{mL}$ penicillin, and
$100 \mu \mathrm{g} / \mathrm{mL}$ streptomycin at $37{ }^{\circ} \mathrm{C}$ in $5 \% \mathrm{CO}_{2}$ atmosphere. Cells were seeded in a $75-\mathrm{cm}^{2}$ flask, and when $70-80 \%$ of confluence was reached, cells were subcultured using $1 \mathrm{~mL}$ of TrypLETM per 25-mL flask. For experiments, cells were grown in multiwell plates. When cells reached the desired confluence, the monolayers were washed with DMEM and were incubated under different conditions according to the experiments.

\section{Preparation of Metvan Solutions}

Fresh stock solutions of Metvan were prepared in dimethyl sulfoxide (DMSO) at $20 \mathrm{mM}$ concentration and were diluted according to the concentrations indicated in the legends of the figures. Precautions should be taken with the maximum concentration of DMSO in the well plate. We used $0.5 \%$ as the maximum DMSO concentration in order to avoid toxic effects of this solvent on cells.

In the case of cis-platin, the complex was dissolved in a $0.9 \% \mathrm{NaCl}$ solution.

Besides, to evaluate the speciation effects of Metvan on antitumor activity, each concentration of Metvan (0.25$100 \mu \mathrm{M}$ ) was incubated at $37^{\circ} \mathrm{C}$ for $1 \mathrm{~h}$ (aged) and then add to the cell in culture.

\section{MTT Assay}

The MTT assay was performed according to T. Mosmann [17]. Briefly, cells were seeded in a 96-multiwell dish, allowed to attach for $24 \mathrm{~h}$ and treated with different concentrations of complexes at $37^{\circ} \mathrm{C}$ for $24 \mathrm{~h}$. After that, the medium was changed and the cells were incubated with $0.5 \mathrm{mg} / \mathrm{mL}$ MTT under normal culture conditions for $3 \mathrm{~h}$. Cell viability was marked by the conversion of the tetrazolium salt MTT (3-(4,5-dimethylthiazol-2-yl)-2,5-diphenyl-tetrazolium-bromide) to a colored formazan by mitochondrial dehydrogenases. Color development was measured spectrophotometrically in a Microplate Reader (7530, Cambridge Technology, Inc., USA) at $570 \mathrm{~nm}$ after cell lysis in DMSO $(100 \mu \mathrm{L} /$ well $)$. Cell viability was plotted as the percentage of the control value.

\section{Statistical Methods}

At least three independent experiments were performed for each experimental condition. Results are expressed as $\%$ basal and represent the mean \pm SEM. Statistical differences were analyzed using the ANOVA test.

\section{Computational Details}

In order to obtain the geometry of the complex corresponding to the state of lowest energy, it was modeled from 
crystallographic data of the analogous $\left[\mathrm{VO}\left(\mathrm{SO}_{4}\right)(\text { ophen })_{2}\right]$. $8 \mathrm{H}_{2} \mathrm{O}$ complex [16] and optimized under the considerations of the theory of functional density (DFT), with the method developed by Truhlar known as M06L [18] as implemented in the Gaussian 09 software package [19] and using a set of triple-zeta quality bases with polarization functions (def2TZPP) for all atoms plus diffuse functions for the sulfur and oxygen atoms (TZVPPD) [20].

Vibrational analysis was carried out to confirm that this structure is a minimum on the potential energy surfaces. Furthermore, the bands of the spectra were also calculated to compare them with the experimental data and to support the assignment of the observed vibrational modes.

\section{Results and Discussion}

\section{Structural Characteristics of the Complex}

The computer optimized structure of the complex is shown in Fig. 1. The vanadium presents a distorted octahedral coordination. The equatorial plane is occupied by the N(2) atom of one of the ophen ligands, the $\mathrm{N}(3)$ and $\mathrm{N}(4)$ atoms of the second ligand and the vanadyl $\mathrm{V}=\mathrm{O}$-oxygen atom whereas the axial positions are conformed by the $\mathrm{N}(1)$ atom of the first ring ligand and the $\mathrm{O}(3)$ atom of the sulfato moiety, generating a $\mathrm{VO}_{2} \mathrm{~N}_{4}$ coordination sphere.

Selected bond distances and angles are shown in Table 1. The $\mathrm{V}=\mathrm{O}$ distance is similar to those determined experimentally by $\mathrm{X}$-ray crystallography, in the cases of $\left[\mathrm{VO}\left(\mathrm{SO}_{4}\right)(\text { ophen })_{2}\right] \cdot 8 \mathrm{H}_{2} \mathrm{O}[16],[\mathrm{VO}($ oda $)($ ophen $)] \cdot 1.5 \mathrm{H}_{2} \mathrm{O}$ [21], and [ $\mathrm{VO}\left(\right.$ oda)(bipy)] $\cdot \mathrm{H}_{2} \mathrm{O}$ [22]. The $\mathrm{V}-\mathrm{N}$ distance trans to this bond, is somewhat larger than the other $\mathrm{V}-\mathrm{N}$ distances, as also found in the case of $\left[\mathrm{VO}\left(\mathrm{SO}_{4}\right)(\text { ophen })_{2}\right] \cdot 8 \mathrm{H}_{2} \mathrm{O}[16]$.

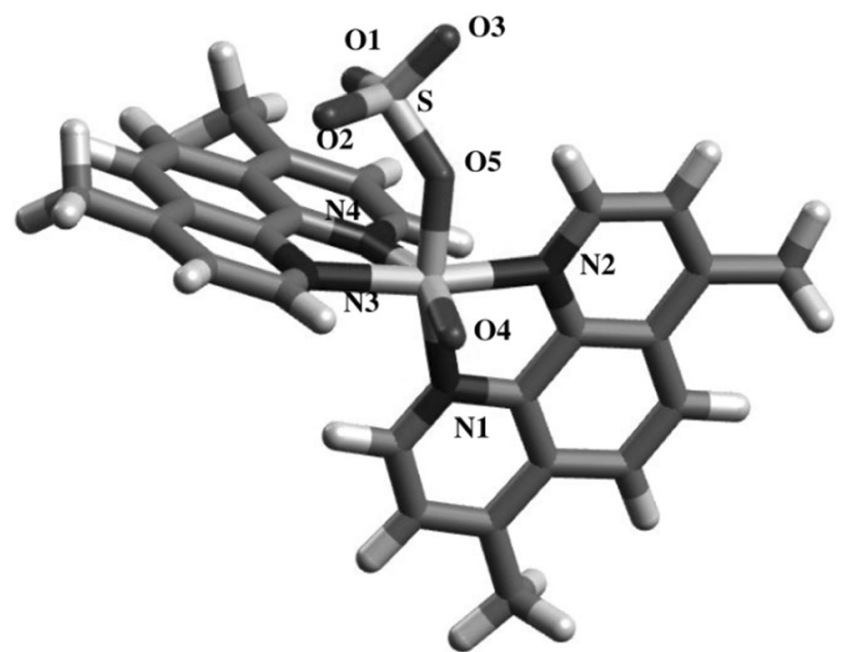

Fig. 1 Optimized structure of the $\left[\mathrm{VO}\left(\mathrm{SO}_{4}\right)\left(\mathrm{Me}_{2} \text {-ophen }\right)_{2}\right]$ obtained by the DFT calculations.
Table 1 Selected bond distances $(\AA)$ and angles $\left({ }^{\circ}\right)$ calculated for the $\left[\mathrm{VO}\left(\mathrm{SO}_{4}\right)\left(\mathrm{Me}_{2}-\right.\right.$ ophen $\left.)_{2}\right] \cdot 3 \mathrm{H}_{2} \mathrm{O}$ complex

\begin{tabular}{lr} 
Bond distances & \\
$\mathrm{V}-\mathrm{O}_{4}$ & 1.609 \\
$\mathrm{~V}-\mathrm{O}_{5}$ & 1.838 \\
$\mathrm{~V}_{-} \mathrm{N}_{1}$ & 2.248 \\
$\mathrm{~V}_{-} \mathrm{N}_{2}$ & 2.173 \\
$\mathrm{~V}-\mathrm{N}_{3}$ & 2.104 \\
$\mathrm{~V}-\mathrm{N}_{4}$ & 2.319 \\
$\mathrm{~S}-\mathrm{O}_{5}$ & 1.628 \\
$\mathrm{~S}-\mathrm{O}_{1}$ & 1.459 \\
$\mathrm{~S}-\mathrm{O}_{2}$ & 1.454 \\
$\mathrm{~S}-\mathrm{O}_{3}$ & 1.442 \\
$\mathrm{Bond}$ angles & \\
$\mathrm{O}_{4}-\mathrm{V}-\mathrm{O}_{5}$ & 112.1 \\
$\mathrm{~N} 1-\mathrm{V}-\mathrm{N} 2$ & 73.8 \\
$\mathrm{~N} 3-\mathrm{V}-\mathrm{N} 4$ & 73.4 \\
$\mathrm{~N} 1-\mathrm{V}-\mathrm{N} 3$ & 170.2 \\
$\mathrm{~N} 1-\mathrm{V}-\mathrm{N} 4$ & 77.6 \\
$\mathrm{~N} 2-\mathrm{V}-\mathrm{N} 3$ & 165.2 \\
$\mathrm{~N} 2-\mathrm{V}-\mathrm{N} 4$ & 92.5 \\
$\mathrm{C} 2-\mathrm{O} 1-\mathrm{C} 2{ }^{\prime}$ & 116.8 \\
$\mathrm{O} 1-\mathrm{C} 2-\mathrm{C} 1$ & 113.0 \\
$\mathrm{O} 1-\mathrm{C} 2^{\prime}-\mathrm{C} 1^{\prime}$ & 113.0 \\
$\mathrm{~N} 1-\mathrm{V}-\mathrm{N} 2$ & 75.8 \\
$\mathrm{O} 5-\mathrm{V}-\mathrm{N} 1$ & 103.7 \\
$\mathrm{O} 5-\mathrm{V}-\mathrm{N} 2$ & 103.7 \\
$\mathrm{O} 2-\mathrm{V}-\mathrm{N} 1$ & 85.9 \\
$\mathrm{O} 2-\mathrm{V}-\mathrm{N} 2$ & 149.0 \\
$\mathrm{O} 2^{\prime}-\mathrm{V}-\mathrm{N} 1$ & 149.0 \\
$\mathrm{O} 2^{\prime}-\mathrm{V}-\mathrm{N} 2$ & \\
$\mathrm{O} 1-\mathrm{V}-\mathrm{N} 1$ & $\mathrm{O} 1-\mathrm{V}-\mathrm{N} 2$ \\
\hline
\end{tabular}

\section{Vibrational Spectrum of $\left[\mathrm{VO}\left(\mathrm{SO}_{4}\right)\left(\mathrm{Me}_{2}-\mathrm{Ophen}\right)_{2}\right] \cdot 3 \mathrm{H}_{2} \mathrm{O}$}

In order to analyze the FTIR spectrum of the complex, we have compared this spectrum with those of the free 4,7-dimethyl-1,10-phenanthroline and $o$-phenanthroline [23-26]. The spectrum obtained for the $\left[\mathrm{VO}\left(\mathrm{SO}_{4}\right)\left(\mathrm{Me}_{2} \text {-ophen }\right)_{2}\right]$. $3 \mathrm{H}_{2} \mathrm{O}$ complex is shown in Fig. 2 and the proposed assignment is presented in Table 2 . The assignments are additionally supported by information provided by well-known standard reference texts $[27,28]$ and by our DFT calculations. They are briefly commented, as follows:

- The stretching vibrations of the water molecules (not shown in Fig. 2) generate a very strong and relatively broad band centered at $3426 \mathrm{~cm}^{-1}$. The corresponding deformational modes, $\delta\left(\mathrm{H}_{2} \mathrm{O}\right)$, are surely overlapped by the band multiplex located between 1624 and $1422 \mathrm{~cm}^{-1}$. The position of the stretching band suggests the 


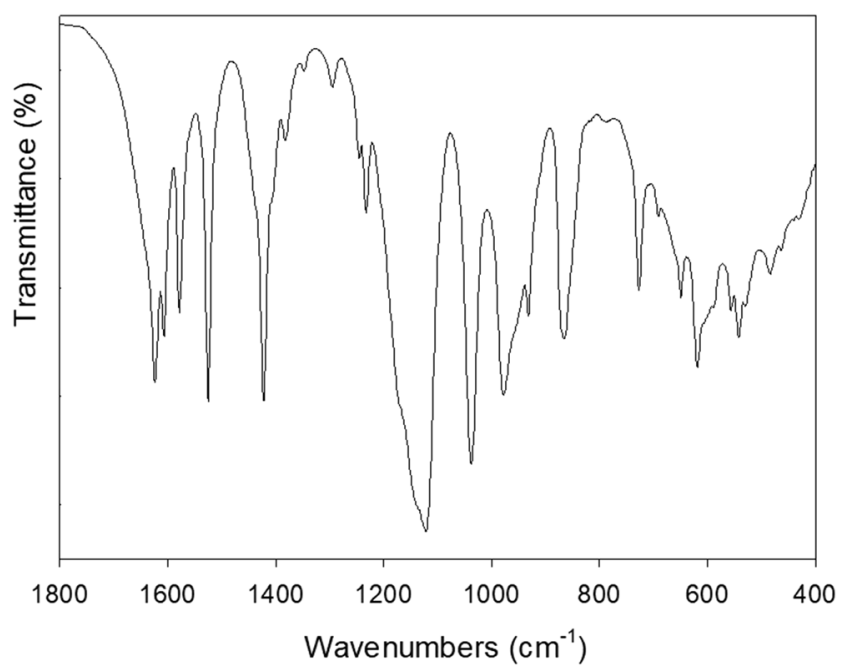

Fig. 2 FT infrared spectra of $\left[\mathrm{VO}\left(\mathrm{SO}_{4}\right)\left(\mathrm{Me}_{2} \text {-ophen }\right)_{2}\right] \cdot 3 \mathrm{H}_{2} \mathrm{O}$ in the spectral range between 1800 and $400 \mathrm{~cm}^{-1}$

participation of these water molecules in $\mathrm{H}$ bridges of medium length [29].

- The characteristic stretching vibrations of the $\mathrm{CH}_{3}$ groups (also not shown in Fig. 2) are found as very weak IR bands in the usually expected ranges $[27,28]$. The corresponding deformational modes are coupled with bands of the $o$-phenanthroline skeleton.

Table 2 Assignment of the FTIR spectrum of $\left[\mathrm{VO}\left(\mathrm{SO}_{4}\right)\left(\mathrm{Me}_{2}-\right.\right.$ ophen) $\left.)_{2}\right] \cdot 3 \mathrm{H}_{2} \mathrm{O}$ (band positions in $\mathrm{cm}^{-1}$ )

\begin{tabular}{|c|c|}
\hline Band position & Assignment \\
\hline 3426 s,br & $v(\mathrm{OH})\left(\mathrm{H}_{2} \mathrm{O}\right)$ \\
\hline $3086 \mathrm{vw}, 3055 \mathrm{sh}$ & ophen- $-(\mathrm{CH})_{\text {in plane }}$ \\
\hline 2923 w & $v_{\mathrm{as}}\left(\mathrm{CH}_{3}\right)$ \\
\hline $2853 \mathrm{vw}$ & $v_{\mathrm{s}}\left(\mathrm{CH}_{3}\right)$ \\
\hline $1624 \mathrm{~s}, 1607 \mathrm{~m}$ & ophen- $\gamma_{\text {ring }}$ \\
\hline $1578 \mathrm{~s}, 1525 \mathrm{vs}$ & ophen- $\nu_{\text {ring }}$ \\
\hline 1422 vs & $\delta_{\text {as }}\left(\mathrm{CH}_{3}\right)+$ ophen $-\delta(\mathrm{CH})_{\text {in plane }}$ \\
\hline $1382 \mathrm{vw}$ & $\delta_{\mathrm{s}}\left(\mathrm{CH}_{3}\right)+$ ophen $-\delta(\mathrm{CH})_{\text {in plane }}$ \\
\hline $1348 \mathrm{w}, 1295 \mathrm{w}$ & ophen- $\delta(\mathrm{CH})_{\text {in plane }}+$ ophen- $-v_{\text {ring }}$ \\
\hline $1245 \mathrm{w}, 1232 \mathrm{~m}$ & ophen- $\nu_{\text {ring }}$ \\
\hline $1171 \mathrm{sh}, 1142 \mathrm{sh}, 1122 \mathrm{vs}$ & $v_{\mathrm{as}}\left(\mathrm{SO}_{4}\right)$ \\
\hline 1038 vs & ophen- $\delta(\mathrm{CH})_{\text {in plane }}+$ ophen- $\nu_{\text {ring }}$ \\
\hline $977 \mathrm{~s}, 960 \mathrm{sh}$ & $v(\mathrm{~V}=\mathrm{O})$ \\
\hline $931 \mathrm{w}$ & ophen- $\delta(\mathrm{CH})_{\text {out of plane }}$ \\
\hline $866 \mathrm{~s}$ & ophen- $\nu_{\text {ring }}$ \\
\hline $727 \mathrm{~s}$ & ophen- $\delta(\mathrm{CH})_{\text {out of plane }}$ \\
\hline $691 \mathrm{vw}$ & ophen- $\delta(\mathrm{CH})_{\text {in plane }}$ \\
\hline $649 \mathrm{w}, 618 \mathrm{~m}$ & $v_{4}\left(\mathrm{SO}_{4}\right)$ \\
\hline $556 \mathrm{vw}, 542 \mathrm{~m}$ & ophen- $\nu_{\text {ring }}$ \\
\hline $484 \mathrm{w}$ & ophen- $\delta(\mathrm{CH})_{\text {in plane }}$ \\
\hline
\end{tabular}

$v s$, very strong; $s$, strong; $m$, medium; $w$, weak, $v w$, very weak; $b r$, broad; sh, shoulder
- The $o$-phenanthroline bands, which clearly dominate this spectrum, were assigned on the basis of previous studies of the free molecule [23-26]. In general, most of the characteristic ring bands in the $1700-1300 \mathrm{~cm}^{-1}$ region are slightly displaced to higher frequencies upon coordination and slight displacements and/or intensity changes were also observed in other spectral regions. This is a behavior which can be considered as typical for $o$ phenanthroline complexes [30].

- The spectroscopic behavior of the sulfato ligand is particularly interesting. As $\mathrm{SO}_{4}{ }^{2-}$ acts as a monodentate ligand its symmetry is reduced from $T_{d}$ to $\mathrm{C}_{3 \mathrm{v}}$. Therefore, in the stretching region, one may expect the splitting of the triple degenerated IR-active antisymmetric mode, $v_{3}\left(\mathrm{~F}_{2}\right)$, into two IR-active components, and the activation of the IR forbidden symmetric stretching mode, $v_{1}\left(\mathrm{~A}_{1}\right)$ [31]. But in the present case, the $v_{3}$-vibration is seen as unique and very strong IR band, with two weak shoulders on its higher-energy side, and no evidence for the presence of a band assignable to the symmetric stretching, $v_{1}$, was found. In the DFT calculation, this band is predicted to lie at $1064 \mathrm{~cm}^{-1}$. Interestingly, no evidence for this symmetric stretching vibration could also be detected in the Raman spectrum, in which this vibration is expected to be particularly intense [32]. In the case of the antisymmetric deformation mode of this anion, $v_{4}\left(F_{2}\right)$, the two expected IR components were clearly identified. In the Raman spectrum, it was also possible to identify a medium intensity line located at $416 \mathrm{~cm}^{-1}$, assignable to the symmetric deformation of this anion. This finding is not totally unexpected as this vibrational mode is known to be relatively intense in the Raman spectrum [33]. The theoretically calculated value for this Raman band is $436 \mathrm{~cm}^{-1}$. In conclusion, the overall spectroscopic behavior of the bonded sulfato anion clearly suggests that this ligand remains scarcely distorted after coordination.

- The characteristic $v(\mathrm{~V}=\mathrm{O})$ breathing was not so easy to identify as in other similar complexes, as it is apparently partially overlapped by ophen vibrations. In the Raman spectrum, this vibration appears as the strongest signal, located at $990 \mathrm{~cm}^{-1}$, whereas in the IR spectrum, it is found at $977 \mathrm{~cm}^{-1}$, both values in excellent agreement with the results of our DFT calculation which predicted this band at $984 \mathrm{~cm}^{-1}$, in both spectra. Its position is comparable to those found in other analogous $\mathrm{VO}^{2+}$ complexes, for example, in $\left.\left[\mathrm{VO}\left(\mathrm{SO}_{4}\right) \text { (ophen }\right)_{2}\right] \cdot 8 \mathrm{H}_{2} \mathrm{O}$ [16], [VO(oda)(ophen) $] \cdot 1.5 \mathrm{H}_{2} \mathrm{O}$ [21], [VO(oda)(bipy)] $\mathrm{H}_{2} \mathrm{O}$ [22], [VO (ODA) $(\mathrm{dppz})] \cdot 3 \mathrm{H}_{2} \mathrm{O}$ [34], and $\left[\mathrm{VO}\left(\mathrm{SO}_{4}\right)\left(\mathrm{H}_{2} \mathrm{O}\right)_{2}(\mathrm{dppz})\right] \cdot 2 \mathrm{H}_{2} \mathrm{O}[35]$.

- Ligand-to-metal vibrations have not been identified. $v(\mathrm{~V}-\mathrm{O})$ stretching modes are probably located below 


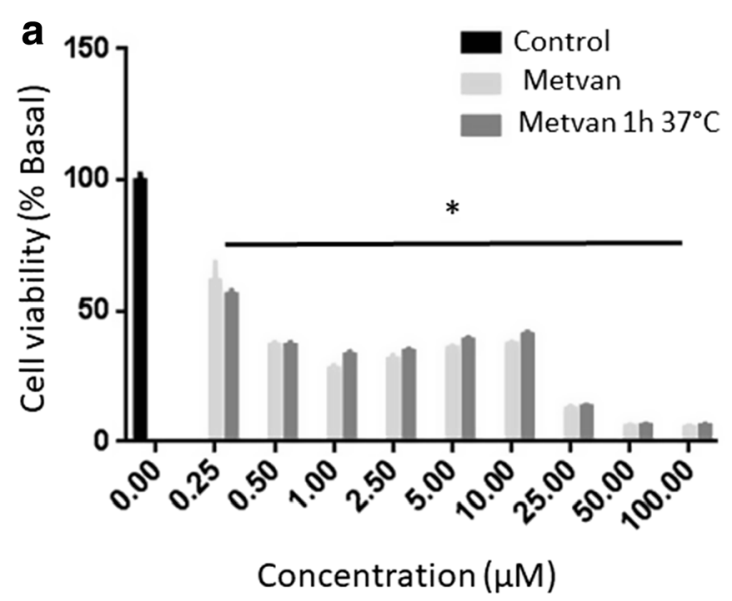

Fig. 3 Evaluation of the mitochondrial succinate dehydrogenase activity by the MTT assay in HT-29 (a) and MG-63 (b) cells in culture. Human cancer cells were incubated with different doses $(0.25-100 \mu \mathrm{M})$ of the

$450 \mathrm{~cm}^{-1}$ whereas $v(\mathrm{M}-\mathrm{N})$ vibrations involving the nitrogen atoms of $o$-phenanthroline are usually expected to lie below $300 \mathrm{~cm}^{-1}$ [36].

In summary, the performed theoretical study allows a first insight into the overall geometry and structural characteristics of Metvan, whereas the spectroscopic study, consistent with the proposed structural model, suggests that the sulfato moiety remains scarcely distorted after coordination to the metal center.

\section{Effects of Metvan on Human Osteosarcoma and Colon Adenocarcinoma Cell Viability}

As stated above, Metvan was identified as one of the most promising multitargeted anticancer vanadium compounds with apoptosis-inducing activity, even at very low concentrations $(0.5-5 \mu \mathrm{M})[9]$.

Considering the high accumulation of vanadium in the bone [37] and the successful antitumor activity of Metvan in different types of tumors, it was of high interest to determine the effect of this compound on human bone and human colorectal cancer cell lines because these kinds of tumors are very important and prevalent in the population. In particular, in this

Table $3 \quad \mathrm{IC}_{50}$ values of Metvan and cis-platin in HT-29 and MG-63 cells after $48 \mathrm{~h}$ of incubation

\begin{tabular}{lll}
\hline & HT-29 $(\mu \mathrm{M})$ & MG-63 $(\mu \mathrm{M})$ \\
\hline Metvan (fresh) & $0.39 \pm 0.07$ & $0.75 \pm 0.02$ \\
Metvan 1 h, $37^{\circ} \mathrm{C}$ (aged) & $0.33 \pm 0.09$ & $0.83 \pm 0.18$ \\
cis-Platin & $21 \pm 2.3$ & $10.5 \pm 1.0$ \\
\hline
\end{tabular}

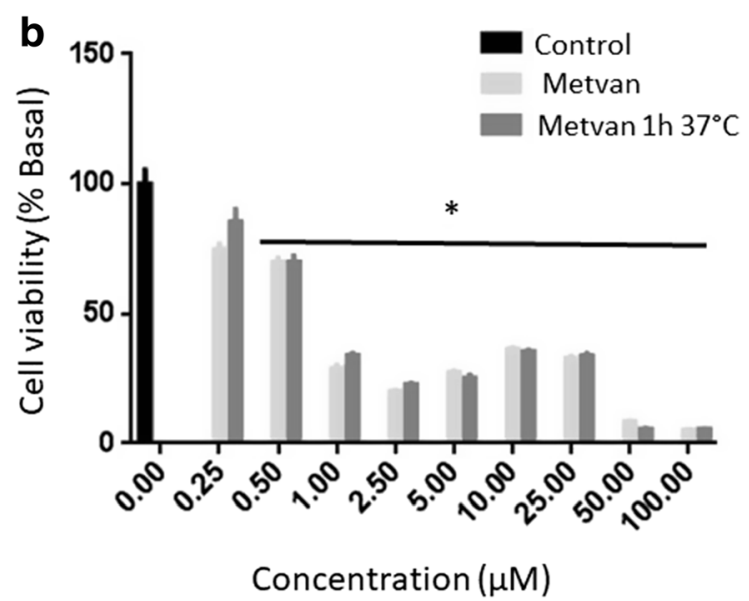

complex for $48 \mathrm{~h}$ at $37^{\circ} \mathrm{C}$. After incubation, cell viability was determined by the MTT assay. Results are expressed as \% basal and represent the mean \pm SEM, $n=18, *$ Significant differences vs. control $(p<0.01)$

study, and as a part of a project devoted to the characterization of antitumoral properties of vanadium compounds, we have tested the effect of Metvan on HT-29 human colon adenocarcinoma and MG-63 human osteosarcoma cell lines.

Figure 3 shows the effects of Metvan on the mitochondria metabolism of HT-29 (a) and MG-63 cells (b). As it can be seen, the complex caused a concentration-related inhibition from 0.25 to $100 \mu \mathrm{M}$ in both cell lines with statistically significant differences versus basal condition $(* p<0.01)$. The control conditions represented as the percentage of basal level.

Table 3 shows that the $\mathrm{IC}_{50}$ values for HT-29 are $0.39 \pm$ $0.07 \mu \mathrm{M}$ (fresh Metvan) and $0.33 \pm 0.09 \mu \mathrm{M}$ (aged Metvan) whilst for MG-63, the values are $0.75 \pm 0.02 \mu \mathrm{M}$ (fresh Metvan) and $0.83 \pm 0.18 \mu \mathrm{M}$ (aged Metvan). These results, considered together, show that the anticancer activity of Metvan is much stronger in colorectal tumor cells than in bone cancer cells. On the other hand, the biological results between fresh and aged Metvan are similar, suggesting that the speciation of the complex does not affect its anticancer activity towards colorectal and bone cancer cells.

On the other hand, and as is also shown in Table 3, Metvan displays better antitumor performance than cis-platin in both cell lines showing 60 times lower $\mathrm{IC}_{50}$ for HT-29 and 13 times lower $\mathrm{IC}_{50}$ for MG-63.

\section{Conclusions}

Previous studies, initiated around 20 years ago, have been shown that Metvan presents potent cytotoxic activity against brain and breast cell lines and induced apoptosis, at low micromolecular concentrations, in primary leukemic cells $[10-12,16]$. The present study clearly extends these results including two new and important cell lines in vitro, also showing that the vanadium complex is the active species. 
On the light of all the so far available results, it is suggested that it may be important to continue biological/biochemical studies with Metvan, including 3D tumor models and in vivo experiments, before to attempt new clinical trials. In this context, it is also important to explore novel tumor cell lines in order to attain wider information about the antitumor activity and into the general chemical and biological behavior of this complex.

Funding Information This research was supported by the Universidad Nacional de La Plata (Projects X/690 and X/673), the Agencia Nacional de Promoción Científica y Tecnológica-ANPCyT (PICT 2014-2223), and the Consejo Nacional de Investigaciones Científicas y TécnicasCONICET (PIP 0034). IEL and BSPC are members of the Research Career from CONICET; MCR has a fellowship from CONICET.

\section{Compliance with Ethical Standards}

Conflict of Interest The authors declare that they have no conflict of interest.

Publisher's Note Springer Nature remains neutral with regard to jurisdictional claims in published maps and institutional affiliations.

\section{References}

1. Evangelou AM (2002) Vanadium in cancer treatment. Crit Rev Oncol Hematol 42:249-265

2. Bishayee A, Waghray A, Patel MA, Chatterjee M (2010) Vanadium in the detection, prevention and treatment of cancer: the in vivo evidence. Cancer Lett 294:1-12

3. Rehder D (2013) Vanadium. Its role for humans. In: Sigel A, Sigel $\mathrm{H}$, Sigel RKO (eds) Metal ions in life sciences Vol 13: Interrelation between essential metal ions and human diseases. Springer, Dordrecht, pp 139-169

4. Köpf-Maier P (1993) Antitumor bis(cyclopentadienyl)metal complexes. In: Keppler BK (ed) Metal complexes in cancer chemotherapy. Verlag Chemie, Weinheim, pp 259-296

5. Köpf-Maier P, KöpfH (1994) Organometallic titaninum, vanadium, niobium, molybdenum and rhenium complexes - early transition metal antitumor drugs. In: Fricker SP (ed) Metal compounds in cancer therapy. Chapman \& Hall, London, pp 109-146

6. Rehder D (2012) The potentiality of vanadium in medicinal applications. Fut Med Chem 4:1823-1837

7. Costa Pessoa J, Etcheverry SB, Gambino D (2015) Vanadium compounds in medicine. Coord Chem Rev 301/302:24-48

8. Costa-Pessoa J (2015) Thirty years through vanadium chemistry. J Inorg Biochem 147:4-24

9. Leon IE, Cadavid-Vargas JF, Di Virgilio AL, Etcheverry SB (2016) Vanadium, ruthenium and copper compounds: a new class of nonplatinum metallodrugs with anticancer activity. Curr Med Chem 23: $1-37$

10. Narla RK, Dong Y, Klis D, Uckun FM (2001) Bis (4,7-dimethyl-1, 10- phenathroline)sulfatooxovanadium(IV) as a novel antileukemic agent with matrix metalloproteinase inhibitory activity. Clin Cancer Res 7:1094-1101

11. Narla RK, Chen CL, Dong Y, Uckun FM (2001) In vivo antitumor a c tivity of bis $((4,7-\mathrm{dim}$ e thy $1-1,10-$ phenathroline) sulfatooxovanadium(IV) \{METVAN $\left.\left.\left[\mathrm{VO}\left(\mathrm{SO}_{4}\right)\left(\mathrm{Me}_{2}-\mathrm{Phen}\right)_{2}\right]\right\}\right)$. Clin Cancer Res 7:2124-2133
12. D’Cruz OJ, Uckun FM (2002) Metvan: a novel oxovanadium(IV) complex with broad spectrum anticancer activity. Expert Opin Investig Drugs 11:1829-1936

13. Sanna D, Ugone V, Micera G, Buglyó P, Bíró L, Garribba E (2017) Speciation in human blood of Metvan, a vanadium based potential anti-tumor drug. Dalton Transact 46:8950-8967

14. Levina A, Crans DC, Lay PA (2017) Speciation on metal drugs, supplements and toxins and bodily fluids controls in vitro activities. Coord Chem Rev 352:473-498

15. Le M, Rathje O, Levina A, Lay PA (2017) High cytotoxicity of vanadium(IV) complexes with 1,10-phenanthroline and related ligands is due to decomposition in cell culture medium. J Biol Inorg Chem 22:663-672

16. Dong Y, Narla RK, Sudbeck E, Uckun FM (2000) Synthesis, X-ray structure, and anti-leukemik activity of oxovanadium(IV) complexes. J Inorg Biochem 78:321-330

17. Mosmann T (1983) Rapid colorimetric assay for cellular growth and survival: application to proliferation and cytotoxicity assays. J Immunol Methods 65:55-63

18. Zhao Y, Truhlar DG (2008) The M06 suite of density functionals for main group thermochemistry, thermochemical kinetics, noncovalent interactions, excited states, and transition elements: two new functionals and systematic testing of four M06-class functionals amd 12 other functionals. Theor Chem Accounts 120:215241

19. Frisch MJ, Trucks GW, Schlegel HB, Scuseria GE, Robb MA, Cheeseman JR, Scalmani G, Barone V, Mennucci B, Petersson GA, Nakatsuji H, Caricato M, Li X, Hratchian HP, Izmaylov AF, Bloino J, Zheng G, Sonnenberg JL, Hada M, Ehara M, Toyota K, Fukuda R, Hasegawa J, Ishida M, Nakajima T, Honda Y, Kitao O, Nakai H, Vreven T, Montgomery JJA, Peralta JE, Ogliaro F, Bearpark M, Heyd JJ, Brothers E, Kudin KN, Staroverov VN, Keith T, Kobayashi R, Normand J, Raghavachari K, Rendell A, Burant JC, Iyengar SS, Tomasi J, Cossi M, Rega N, Millam JM, Klene M, Knox JE, Cross JB, Bakken V, Adamo C, Jaramillo J, Gomperts R, Stratmann RE, Yazyev O, Austin AJ, Cammi R, Pomelli C, Ochterski JW, Martin RL, Morokuma K, Zakrzewski VG, Voth GA, Salvador P, Dannenberg JJ, Dapprich S, Daniels AD, Farkas O, Foresman JB, Ortiz JV, Cioslowski J, Fox DJ (2010) Gaussian-09. Gaussian Inc., Wallingford

20. Weigend F, Ahlrichs R (2005) Balanced basis sets of split valence, triple zeta valence and quadruple zeta valence qualify for $\mathrm{H}$ to $\mathrm{Rn}$ : design and assessment of accuracy. Phys Chem Chem Phys 7: 3297-3305

21. Álvarez L, Grirrane A, Moyano R, Álvarez E, Pastor A, Galindo A (2010) Comparison of the coordination capabilities of thiodiacetate and oxydiacetate ligands through the $\mathrm{X}$-ray characterization and DFT studies of [VO(dta) (phen)] $4 \mathrm{H}_{2} \mathrm{O}$ and [VO(oda)(phen)] $1.5 \mathrm{H}_{2} \mathrm{O}$. Polyhedron 29:3028-3035

22. del Rio D, Galindo A, Vicente R, Mealli C, Ienco A, Mais D (2003) Synthesis, molecular structure and properties of oxo-vanadium(IV) complexes containing the oxydiacetate ligand. Dalton Transact. 2003:1813-1820

23. Altmann W, Perkampus HH (1979) Normalkoordinatenanalyse der Phenanthroline. Teil I. Die planaren Grundschwingungen. Spectrochim Acta 35A:253-257

24. Altmann W, Kleindienst H, Perkampus HH (1979) Normalkoordinatenana- lyse der Phenanthroline. Teil II. Die outof-plane Schwingungen. Spectrochim Acta 35A:259-262

25. Thornton DA, Watkins GM (1991) A full vibrational assignment $\left(4000-50 \mathrm{~cm}^{-1}\right)$ of 1,10-phenanthroline and its perdeuterated analogue. Spectrochim Acta 47A:1085-1096

26. Reiher M, Brehm G, Schneider S (2004) Assignment of vibrational spectra of 1,10-phenanthroline by comparison with frequencies and Raman intensities from density functional calculations. J Phys Chem A108:734-742 
27. Lin-Vien D, Colthup NB, Fateley WG, Grasselli JG (1991) The handbook of infrared and Raman characteristic frequencies of organic molecules. Academic Press, Boston

28. Smith B (1999) Infrared spectral interpretation. CRC-Press, Boca Raton

29. Siebert H (1966) Anwendungen der Schwingunsspektroskopie in der Anorganischen Chemie. Springer, Berlin

30. Schilt AA, Taylor RC (1959) Infrared spectra of 1,10phenanthroline metal complexes in the rock salt region below $2000 \mathrm{~cm}^{-1}$. J Inorg Nucl Chem 9:211-221

31. Nakamoto K (1997) Infrared and Raman spectra of inorganic and coordination compounds, 5th edn. J. Wiley, New York

32. Müller A, Baran EJ, Carter RO (1976) Vibrational spectra of oxo-, thio-, and selenometallates of transition elements in the solid state. Struct Bond 26:81-139

33. Weinstock N, Schulze H, Müller A (1973) Assignment of $v_{2}$ (E) and $v_{4}\left(F_{2}\right)$ of tetrahedral species by the calculation of the relative
Raman intensities: the vibrational spectra of $\mathrm{VO}_{4}{ }^{3-}, \mathrm{CrO}_{4}{ }^{2-}$, $\mathrm{MoO}_{4}{ }^{2-}, \mathrm{WO}_{4}{ }^{2-}, \mathrm{MnO}_{4}{ }^{-}, \mathrm{TcO}_{4}{ }^{-}, \mathrm{ReO}_{4}{ }^{-}, \mathrm{RuO}_{4}$ and $\mathrm{OsO}_{4}$. J Chem Phys 59:5063-5067

34. Leon IE, Parajón-Costa BS, Franca CA, Etcheverry SB, Baran EJ (2015) A new oxidovanadium(IV) complex of oxodiacetic acid and dppz: spectroscopic and DFT study. Antitumor action on MG-63 human osteosarcoma cell line. Biol Trace Elem Res 164:198-204

35. Benítez J, Guggeri L, Tomaz I, Costa Pessoa J, Moreno V, Lorenzo J, Avilés FX, Garat B, Gambino D (2009) A novel vanadyl complex with a polypyridyl DNA intercalator as ligand: a potential anti-protozoa and antitumor agent. J Inorg Biochem 103:1386-1394

36. Inskep RG (1962) Infrared spectra of metal complex ions below $600 \mathrm{~cm}^{-1}$. J Inorg Nucl Chem 24:763-776

37. Baran EJ (2008) Vanadium detoxification: chemical and biochemical aspects. Chem Biodivers 5:1475-1484 